This item was submitted to Loughborough's Research Repository by the author.

Items in Figshare are protected by copyright, with all rights reserved, unless otherwise indicated.

\title{
Design, usability and unsafe behaviour in the home
}

PLEASE CITE THE PUBLISHED VERSION

http://www.rospa.com/homesafety/conferences-presentations-events/

\section{PUBLISHER}

The Royal Society for the Prevention of Accidents (@) The author)

VERSION

AM (Accepted Manuscript)

LICENCE

CC BY-NC-ND 4.0

\section{REPOSITORY RECORD}

McDermott, Hilary, Roger Haslam, and Alistair G.F. Gibb. 2019. "Design, Usability and Unsafe Behaviour in the Home". figshare. https://hdl.handle.net/2134/8446. 
This item was submitted to Loughborough's Institutional Repository (https://dspace.lboro.ac.uk/) by the author and is made available under the following Creative Commons Licence conditions.

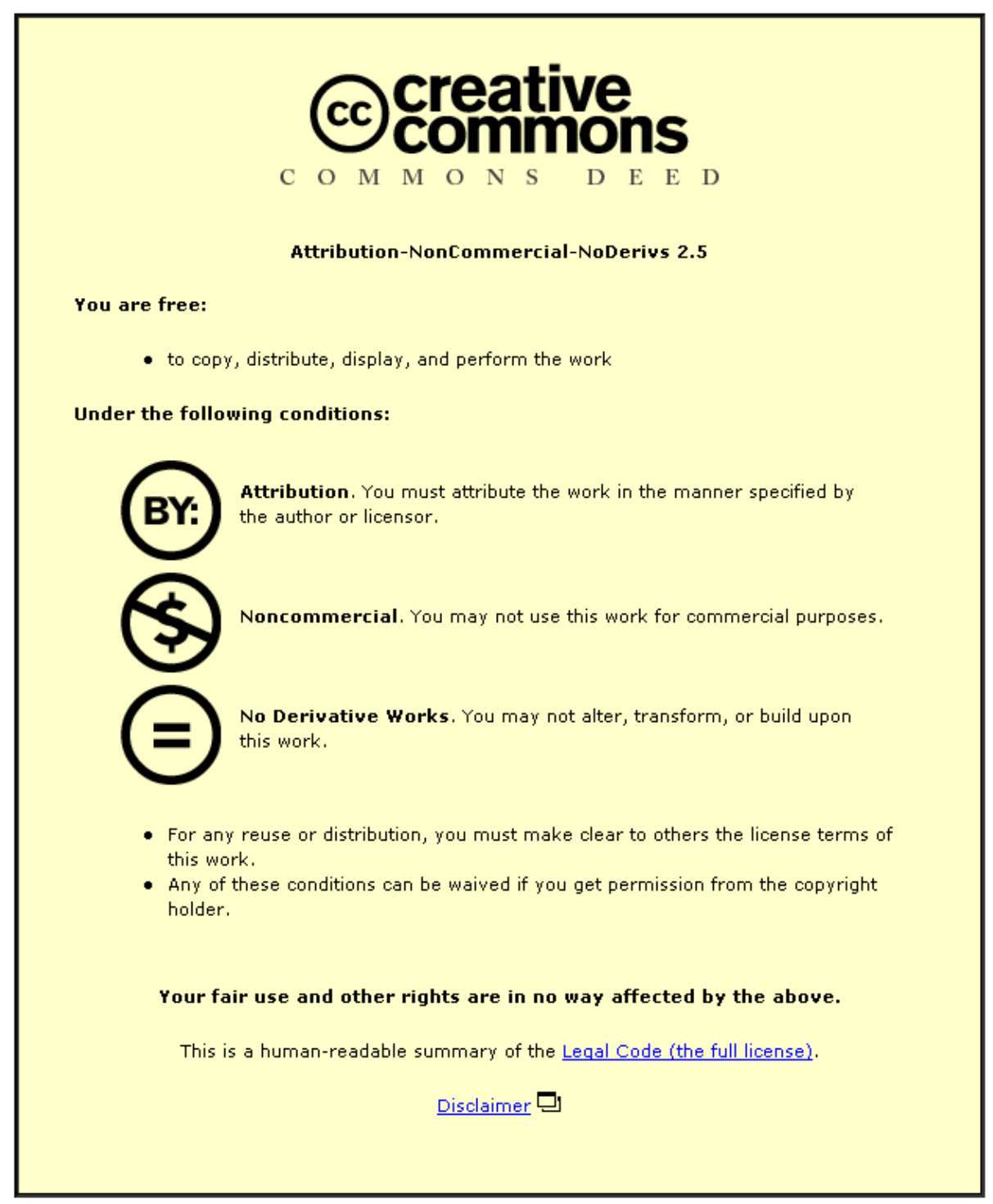

For the full text of this licence, please go to: http://creativecommons.org/licenses/by-nc-nd/2.5/ 
Proceedings ROSPA Home Safety Congress 2004: New Challenges for Home Safety. Chester. $15^{\text {th }}-16^{\text {th }}$ November 2004.

\title{
Design, Usability and Unsafe Behaviour in the Home
}

\author{
Hilary McDermott \\ Health and Safety Ergonomics Unit
}

H.J.McDermott@lboro.ac.uk

Professor Roger Haslam

Professor Alistair Gibb

\section{Loughborough University}

This presentation details the preliminary findings from a recent study undertaken within the Health and Safety Ergonomics Unit at Loughborough University. The research examined occupier behaviour within the home and assessed how such behaviour interacts with design and how this might compromise health and safety.

The problem of home accidents was highlighted over fifty years ago (The London School of Hygiene and Tropical Medicine, 1949) yet they continue to be a significant problem both here in the United Kingdom and abroad. Each year almost 2.8 million home accidents occur within the United Kingdom which result in the casualty requiring hospital treatment and as many cases again where treatment is provided by a General Practitioner (DTI 2001). In addition, it is approximated that millions of home accidents occur each year which result in only minor injury and many more 'near' accidents in which no injury is sustained. The DTI estimate a $20 \%$ increase in non-fatal home accidents by the year 2010, and the associated economic cost of such accidents is estimated at thirty thousand million pounds annually.

In addition to home accidents, dwelling fires are also a major topic of concern. In the year 2003, 64,000 fires occurred within dwellings and over 50,000 of these fires arose due to accidental causes. As a result of these fires, over 400 people were killed and nearly 13,000 sustained injuries. (ODPM 2004).

This research examined occupier behaviour within new build homes. Each year almost 200,000 new homes are completed within the United Kingdom (ODPM 2004). These are marketed in relation to their design, usability and convenience. Innovative items combined with improved safety features make these new homes more attractive to prospective purchasers, indeed, the New Homes Marketing Board report that there is continued growth in customer preference for new build housing. (NHMB 2003).

New build homes must meet the criteria as set out in Building Regulations. Heavily influenced by the Health and Safety at Work Act 1974, current regulations grew out of concerns for health and safety and aim to serve the following broad purposes: - 
- Ensure the health, safety, welfare and convenience of people in and around buildings, including dwellings.

- Ensure the conservation of energy, fuel and power.

- Prevent waste, misuse or contamination of water.

The aim of this study was to collect information regarding behaviour within the home and to ascertain how such behaviour interacts with design to compromise health and safety. Forty in-depth semi-structured interviews were undertaken with new build occupiers. The interview schedule covered a variety of topics including safety features, occupier behaviour and risk perception. Home audits were also undertaken which involved the researcher accompanying occupiers from room to room within their properties and identifying where problems arose with design features and where modifications had been made.

Unsafe behaviours were reported in relation to a number of features and these will be illustrated in relation to the context in which they were described. Firstly, specific behaviours were reported in relation to installed safety features within the home such air vents and fire doors. Draughty air vents were located in the main living room and one example was observed whereby a participant had covered the vent with tin foil to prevent the draught. 26 of the 40 properties were fitted with self-closing fire doors, and in every single one of these properties the owners/occupiers had interfered with these fire doors in some way. Fire doors were wedged open in some way or the self-closers themselves had been removed.

A 34 year old female nurse described the removal of the door closers : -

Oh yeah these stupid...yeah he did, no no no, we picked up on why there were chains on all the doors and he said it's because they are fire doors, in three story houses it's building regs. and we said 'oh ok,' so we moved in and took them all off'

A 50 year old male wheel chair user commented on the fact that he was unable to open his internal fire doors: -

'No, there's no way I could open the doors in a wheelchair, it's just not possible, so I've had to take them off'

These are accounts of deliberate behaviour, whereby the occupiers had made a conscious decision to act in this way. The following quotes describe the motivations driving such behaviour: -

A 21 year old student living in shared accommodation outlined the problem of inadequate lighting: - 
'my only concern is a lack of lighting in the stairwell, that's the reason that door's kept open, just to let a bit of light into there'

A 45 year old housewife explained how she was inconvenienced by noise: -

'I understand the health and safety behind it, but it drives me, it worries me; they really go with a bang. The banging drives me nuts'

A 34 year old mother was concerned about her children trapping their fingers and said: -

'oh God, yeah, the kids did, that was one of the reasons we took them off'

The main determinants of such behaviour are therefore excessive noise, inadequate lighting, inconvenience and accident prevention. The health and safety reasons behind the installed fire doors are obviously understood, it is the design of the doors themselves that drive this behaviour. If the usability of the fire doors were considered during the design phase, this may eliminate these determinants of unsafe behaviour.

Unsafe behaviour was also reported in relation to DIY tasks undertaken within the home, specifically in relation to electrical safety, water safety and the use of Personal Protective Equipment. Few occupiers considered the location of electricity cables and water pipes before drilling into the wall and some admitted to just 'taking chances' when engaging in such tasks: -

A 21 year old male living in shared accommodation commented on the fact that he had no idea where the cables and pipes ran in the property;-

'I've got no idea. You don't think about those things'

He then described how he would drill into the wall without this knowledge: -

No idea, [the walls] sound like they are hollow...it's hard to tell, so no, no idea where they were. It's just straight in'

It is evident that a lack of knowledge/awareness is the major determinant of this behaviour. If the layout of pipes and cables were included within new homeowners information packs this may go someway in preventing risk-taking behaviour in relation to cabling and pipe work.

We often associate health and safety information with accident prevention and forget the associated ill-health issues. A 26 year old male described how his skin problem was exacerbated through not wearing protective equipment: -

'I didn't have any protective equipment...didn't wear PPE or gloves and it actually caused my dermatitis to inflame' 
People did show an awareness for the need for Personal Protective Equipment, but it was evident that the lack of usability of these items prevent it's use: -

A 60 year old male described how he felt regarding it's use: -

'I think a lot of these safety things are awkward, put goggles on and they steam up and you can't see what you are doing and this is one of those things, it's bloody dangerous'

A 21 year old male spoke of the same annoyance: -

'I think it gets in the way, things like goggles and stuff, they just seem to steam up, it's just generally annoying'

Once again, this problem could be tackled at the design phase.

Unsafe behaviour was reported in relation to a number of different everyday contexts that are not controlled by legislation. Accessing the loft is just one example whereby participants were aware of the dangers associated with their behaviour: -

In describing how he accessed his loft a 26 year old male said: -

'That's definitely a major hazard because I've clambered up there using stools and using $G$ [wife] to stand on, it's quite bad.'

A 33 year old male explained the dangers associated with accessing the loft: -

'If you look up there, you've got the loft hatch and if you've got a step ladder, you would have to step on the top rung and try and grab yourself into the loft, but it's a sheer drop right down the stairs, there's no room for error, you're not going to land on the landing, you are going to go straight over'

A 34 year old male described his own dangerous behaviour: -

'For eighteen months it was a rickety old wooden step ladder so it was pretty dangerous, and I had to stand right on top of the handles to climb in'

This conscious and deliberate unsafe behaviour could be prevented in the design and provision of new homes under the control of building regulations. Loft ladders, if fitted as standard would eliminate the various unsafe efforts undertaken by homeowners in accessing their loft space and maybe reduce the number of falls as a consequence. 
Despite a well-publicised public information campaign on the importance of making a fire plan, few homes reported having made an escape plan. $70 \%$ of the sample questioned had not considered a fire escape plan at all: -

A 35 year old female explained that she and her husband had not made a fire plan: -

'Never spoken about it at all'

A 29 year old married male explained:-

'It's funny, it's something we've never discussed'

A 60 year old male described the additional problem of living in a three story property: -

$$
\begin{gathered}
\text { 'No, it's a three story, you'd kill yourself if you } \\
\text { got out of there' }
\end{gathered}
$$

In addition to having not made a fire escape plan, only $17.5 \%$ of the sample reported owning a home fire-extinguisher. In fact the overall take up of consumer safety products was found to be low. Only two of the forty properties visited had a carbon monoxide detector and although all the properties were fitted with mains-fed smoke detectors, over $30 \%$ of occupiers had never tested these and none of them tested the detector on even a monthly basis.

One final example of behaviour highlights the extremes individuals will go to, to overcome what they perceive as a design fault. Part $\mathrm{M}$ of the Building Regulations was first introduced in 1998 and following a growing awareness of the discrimination faced by disabled individuals has since been amended to include provisions aimed at allowing disabled people safe and convenient access to buildings, including dwellings, and the ability to move about within those buildings. The design of new homes only addresses accessibility for the infrequent visitor and fails to fully address the comprehensive needs of the disabled. Ramped access to buildings may allow disabled entry, but unless all exits are also ramped, safe evacuation may be impossible. One of the participants in this study was a wheelchair user, he was able to access his property, but was unable to open his internal fire doors from a seated position in his wheelchair. Safe egress from his property was impossible and he used a self-built ramp in order to do so. The height required for the ramp however made his wheelchair tip dangerously forward, yet this was a behaviour that was practiced on a frequent basis.

These examples of the deliberate behaviours undertaken by individuals within their homes highlight the fact that improvements can be made in the design and provision of new housing. User needs and behaviour needs to be considered from the outset and incorporated within Building Regulations and other installation standards. 
So we are indeed facing new challenges in the attempt to reduce the number of home accidents. Addressing user needs and considering the issues of Environmental

Psychology and Ergonomics within the design phase of home features may be one way of meeting those challenges. 


\section{References}

Department of Trade and Industry (2001) $23^{\text {rd }}$ Annual Report of the Home and Leisure Accident Surveillance System - 1999 data, Department of Trade and Industry, London.

Department of Trade and Industry (1999) Research on the patterns and trends in home accidents. Department of Trade and Industry, London.

New Homes Marketing Board (2003) New Homes Today, Mitton Marketing Solutions.

Office of the Deputy Prime Minister (2004) Fire Statistics Monitor. Issue No 2/04, covering period up to30th June 2003. Taken from http://www.odpm.gov.uk/stellent/groups/odpm_fire/documents/page/odpm_fire_028715. doc visited 06.04.2004

Office of the Deputy Prime Minister (2004) House Building: permanent dwellings started and completed, by tenure, United Kingdom. Taken from http://www.odpm.gov.uk/stellent/groups/odpm control/documents/contentservertemplate lodpm_index.hcst?n=1566\&1=3 visited 06.04.2004

The London School of Hygiene and Tropical Medicine, Public Health Department. The Problem of Home Accidents, The Lancet, Volume 253, Issue 6554, $9^{\text {th }}$ April 1949, Pages $620-622$. 